\title{
Freedom of Journalism in International Human Rights Law
}

\author{
Edward L. Carter \\ Brigham Young University, ed_carter@byu.edu \\ Rosalie Westenskow
}

Follow this and additional works at: https://scholarsarchive.byu.edu/facpub

Part of the Communication Commons

\section{Original Publication Citation}

Edward L. Carter \& Rosalie Westenskow (2020) Freedom of Journalism in International Human Rights Law, Communication Law and Policy, 25:2, 113-143, DOI: 10.1080/ 10811680.2020.1735188

\section{BYU ScholarsArchive Citation}

Carter, Edward L. and Westenskow, Rosalie, "Freedom of Journalism in International Human Rights Law" (2020). Faculty Publications. 4749.

https://scholarsarchive.byu.edu/facpub/4749

This Peer-Reviewed Article is brought to you for free and open access by BYU ScholarsArchive. It has been accepted for inclusion in Faculty Publications by an authorized administrator of BYU ScholarsArchive. For more information, please contact ellen_amatangelo@byu.edu. 


\title{
FREEDOM OF JOURNALISM IN INTERNATIONAL HUMAN RigHTS LAW
}

\author{
EDWARD L. CARTER*
}

\section{ROSALIE WESTENSKOW**}

Contemporary attacks of various types have prompted calls for stronger public support and legal protections for journalism. Around the world, journalism faces not only government regulation that affects editorial content but also economic and corporate pressures as well as lack of public understanding of its societal functions. In the United States, courts and even journalism organizations have been reluctant to define journalism or single it out for special protection. But international human rights law presents a possible solution. This article discusses the international human rights law provisions that protect individuals engaged in journalism. The United Nations Human Rights Committee has laid groundwork to define and protect journalism's unique functions within the larger international law framework for freedom of expression. This groundwork includes the possibility for individual journalism rights to be distinguished from institutional media or press rights. The article contends that such a distinction

\footnotetext{
${ }^{*}$ Professor and Director, Brigham Young University School of Communications.

${ }^{* *}$ Attorney and Independent Researcher, Nonprofit Law Northwest.
} 
has become increasingly important. The international law proportionality test could resolve concerns about defining journalism as a stand-alone fundamental right.

The gruesome state-ordered torture and murder of Saudi Arabian exile Jamal Khashoggi on October 2, 2018 serves as a tragic reminder of the lengths to which autocrats will go to suppress journalism. A group of Saudi agents with close ties to Crown Prince Mohammed bin Salman dismembered Khashoggi, a long-time journalist who commented pointedly on the corruption and failures of both the Crown Prince and U.S. President Donald J. Trump, inside the Saudi consulate in Istanbul. ${ }^{1}$ The extrajudicial killing was caught on audio recording. Khashoggi, a legal United States resident, had entered the consulate to obtain a document prior to marrying his fiancée, Hatice Cengiz. The international legal community condemned the killing, pointedly in the form of an exhaustive report by United Nations Special Rapporteur Agnes Callamard, who called the Saudis' action "a deliberate, premeditated execution." ${ }^{2}$ Yet, the Trump administration prevaricated in holding the Saudis to account. Trump himself acknowledged the billions of dollars flowing from Saudi Arabia to the United States for

\footnotetext{
${ }^{1}$ Annex to the Report of the Special Rapporteur on extrajudicial, summary or arbitrary executions: Investigation into the unlawful death of Mr. Jamal Khashoggi, A/HRC/41/CRP.1 (June 19, 2019) [hereinafter "Khashoggi Report"].

${ }^{2} I d$. at II 235 .
} 
weapons. ${ }^{3}$ When the Saudis finally admitted that Khashoggi died inside the consulate, Trump subserviently said he hoped sanctions would not harm the weapons sales. ${ }^{4}$

Khashoggi's last column, published posthumously in the Washington Post, was eerily prescient:

Arab governments have been given free rein to continue silencing the media at an increasing rate. There was a time when journalists believed the Internet would liberate information from the censorship and control associated with print media. But these governments, whose very existence relies on the control of information, have aggressively blocked the Internet. They have also arrested local reporters and pressured advertisers to harm the revenue of specific publications. ${ }^{5}$

Khashoggi's proposed solution to this global problem was an internationally protected network of news media that could deliver outside news beyond the censorship

\footnotetext{
${ }^{3}$ See David D. Kirkparick \& Carlotta Gall, Audio Offers Gruesome Details of Jamal Khashoggi Killing, Turkish Official Says, N.Y. TIMES, Oct. 17, 2018, available at https://www.nytimes.com/2018/10/17/world/europe/turkey-saudi-khashoggi-dismember.html.

${ }^{4}$ See Associated Press, Trump Puts Saudi Arms Sales Above Inquiry Into Khashoggi Killing, PBS.ORG, June 24, 2019, available at https://www.pbs.org/newshour/world/trump-puts-saudi-arms-salesabove-inquiry-into-khashoggi-killing.

${ }^{5}$ Jamal Khashoggi, What the Arab World Needs Most is Free Expression, WASH. Post, Oct. 17, 2018, available at https://www.washingtonpost.com/opinions/global-opinions/jamal-khashoggi-what-thearab-world-needs-most-is-free-expression/2018/10/17/adfc8c44-d21d-11e8-8c22-fa2ef74bd6d6_story.html.
} 
of national dictators and could also provide honest assessments of the "poverty, mismanagement and poor education" in the Arab world. ${ }^{6}$ Khashoggi believed these difficult problems could be addressed by Arab populations if only journalists backed by the international law community could deliver unfettered and frank news accounts. He concluded, "Through the creation of an independent international forum, isolated from the influence of nationalist governments spreading hate through propaganda, ordinary people in the Arab world would be able to address the structural problems their societies face." 7

The Khashoggi case may be extraordinary for its brutality, but hundreds of journalists around the world today face attacks on a regular basis. Trump has called journalists the "enemy of the people" and suggested that his supporters at rallies should do them harm. ${ }^{8}$ For Trump, "fake news" constitutes any news he does not like. He has managed to convince a large swath of the American population that he faces systemic bias from the news media, and he refuses to acknowledge that journalists could be actually playing their long-established constitutional and societal role to report on his corruption, lies, misogyny and racial scapegoating. In the wake of Khashoggi's death, Trump complimented a member of Congress from Montana, Greg Gianforte, who

\footnotetext{
${ }^{6} I d$.

${ }^{7} I d$

${ }^{8}$ See Dan Macguill, Did Donald Trump Encourage Violence at His Rallies?, SNOPES.COM (nd), https://www.snopes.com/fact-check/donald-trump-incitement-violence/ (accessed January 10, 2020).
} 
physically attacked a Guardian journalist over campaign coverage in early $2018 .{ }^{9}$ Trump is not alone. Journalists around the world face jail time and worse simply for doing their jobs. Further, vigorous journalism in the public interest is hampered by economic forces that have led to mass layoffs, corporate consolidation and alignment of politically partisan institutional media with preferred parties, candidates and office-holders. ${ }^{10}$

Freedom House's 2019 study of global free press issues paints a bleak picture. The report concludes that free press, like democracy worldwide, is in a downward spiral. ${ }^{11}$ The NGO reported that elected democratic leaders, including Trump, should be the staunchest defenders of a free press and yet the opposite is true. The decline of democracy and free press is especially notable in Europe, Eurasia and the Middle East. Right-wing populists, the report says, have weaponized "public denunciations of honest journalists." ${ }^{12}$ The goal of these attacks is to undermine public confidence in journalism's role to hold government accountable to the people. Assaults on press independence are correlated with autocratic "power grabs. . . [and] with entrenched regimes' attempts to crush perceived threats to their control." ${ }^{13}$ Freedom House called for policymakers around the world to refrain from undermining the role of the press.

\footnotetext{
${ }^{9}$ See Emily Cochrane, "That's My Kind of Guy," Trump Says of Republican Lawmaker Who Body-Slammed a Reporter, N.Y. TIMES, Oct. 19, 2018, available at https://www.nytimes.com/2018/10/19/us/politics/trump-greg-gianforte-montana.html.

${ }^{10}$ See Freedom House, Freedom and the Media: A Downward Spiral, https://freedomhouse.org/report/freedom-media/freedom-media-2019 (2019).

${ }^{11} I d$.

${ }^{12} I d$.

${ }^{13} I d$.
} 
The global independent news media envisioned by Khashoggi's final column would require strong protection under international human rights law. In reality, the framework for international law press protections already exists, although its presence sometimes gets obscured amid broader discussion of protections for freedom of expression. This article asserts that an international law protection for journalism exists distinctly from broader free-expression and media-freedom rights in the United Nations Human Rights Committee's interpretations of Article 19 of the International Covenant on Civil and Political Rights, known as ICCPR. Given its status as the leading international human rights law treaty and a key part of what is often called the International Bill of Rights, ICCPR should be carefully studied and implemented. As with the First Amendment to the U.S. Constitution's Press Clause, the international human rights law framework protecting freedom of journalism ${ }^{14}$ deserves renewed attention and support in light of a global wave of autocracy, populism and social media-fueled disinformation in the twenty-first century.

This article contends that international law provides the basis for the function of journalism, conducted by individuals, to be protected independently of institutional press or media rights. While this distinction may not always result in a legal difference, it nonetheless could strengthen public understanding and support of journalism. The article

\footnotetext{
${ }^{14}$ This article uses the phrase "freedom of journalism" in connection with its assertion that an individual journalism right can and should be distinguished from institutional media or press rights within international human rights law. Phrases such as "press freedom" are still used in this article when referencing authors and organizations who have used those phrases, including to indicate both institutional and individual rights.
} 
first reviews the state of the Press Clause in the United States, where journalism traditionally has been protected to an exceptional degree but that protection has been as an indistinguishable part of broad free-speech rights under the First Amendment. Journalism in the United States is suffering a decline in public esteem and legal protection, however. ${ }^{15}$ Next, the article reviews global scholarly literature discussing the potential for individual journalism rights to be distinguished from institutional press or media rights. The article then surveys international human rights law materials for their definition of the functions and unique characteristics of journalism.

\section{Challenges to JournalisM in THE United StateS}

\section{Under the Redundant Press Clause}

The Supreme Court of the United States has never given independent meaning to the Press Clause of the First Amendment to the Constitution. ${ }^{16}$ Although the First Amendment explicitly mentions the press independent of a broad freedom of speech right, the Court's decisions in press cases do not rely on the Press Clause. ${ }^{17}$ One scholar

\footnotetext{
${ }^{15}$ See infra notes 16-62 and accompanying discussion.

${ }^{16}$ Justice Potter Stewart argued in a law journal article for recognition of an institutional press right distinct from the broad free-speech right in the First Amendment, but he did not consider this to be an individual right of journalists: "The primary purpose of the constitutional guarantee of a free press was a similar one: to create a fourth institution outside the Government as an additional check on the three official branches." Potter Stewart, Or of the Press, 26 HASTINGS L.J. 631, 634 (1975).

${ }^{17}$ See, e.g., Richmond Newspapers Inc. v. Virginia, 448 U.S. 555, 573 (1980) (recognizing that institutional news media may serve "as surrogates for the public" in attending and reporting on criminal
} 
concluded that the Supreme Court's tendency to praise the role of journalism in society while deciding press cases on broad free expression grounds had resulted in much "pleasant but purposeless dicta."" The Court followed this pattern in, among others, Near v. Minnesota, ${ }^{19}$ New York Times Co. v. Sullivan ${ }^{20}$ and New York Times Co. v. United States. ${ }^{21}$ Near and the Pentagon Papers case have been viewed as cases about prior restraint in general, not just press rights, and the protections for "freedoms of expression" in Sullivan did not depend wholly on the involvement of a newspaper in the litigation. ${ }^{22}$ The Supreme Court since the early twentieth century considered " $[\mathrm{t}]$ hat freedom of speech and of the press are rights of the same fundamental character...."23 The Court's approach may be due in part to the attitude of journalists and their advocates. ${ }^{24}$ Sonja West chronicled among journalists and advocates "an aversion to the

court proceedings but stating that journalists "enjoy the same right of access as the public" notwithstanding “special seating and priority of entry”); Gertz v. Welch, 418 U.S. 323, 342 (1974) (concluding that institutional press and broadcast media were not immune from liability for defamation of public officials and public figures but rather that a balancing test must be undertaken to weigh reputational interests versus public debate interests); Dun \& Bradstreet, Inc. v. Greenmoss Builders, Inc., 472 U.S. 749, 757-61 (1985) (focusing on the character of statements at issue rather than the media or non-media identity of speakers in a defamation action).

${ }^{18}$ RonNell Andersen Jones, The Dangers of Press Clause Dicta, 48 GA. L. REV. 705 (2014).

19283 U.S. 697 (1931).

20376 U.S. 254 (1964).

21403 U.S. 713 (1971).

22376 U.S. at 271.

${ }^{23}$ Grosjean v. American Press Co., 297 U.S. 233, 244 (1936).

${ }^{24}$ See Sonja R. West, Awakening the Press Clause, 58 UCLA L. REV. 1025 (2011). 
perceived elitism in making the press a select group." ${ }^{25}$ Erik Ugland examined eighty Supreme Court cases involving news media and concluded that news media litigants went to great lengths to place their arguments in the context of broad free-speech rights available to all speakers and not just journalists. ${ }^{26}$ Meanwhile, in the twenty-first century, the lack of explicit distinguishable constitutional protections for journalists in the United States has coincided with government, corporate and social pressures on journalism.

For example, Trump has popularized the phrase "fake news" to refer to any reporting not to his liking. In Trump's lexicon, a reference to "fake news" does not necessarily mean the statements in question are untrue or out of touch with reality. In a book published in June $2019,{ }^{27} \mathrm{CNN}$ reporter Jim Acosta, a frequent target of Trump and Trump administration officials in White House press briefings and public campaign-style rallies around the country, recounted an interaction that suggested Trump himself did not realize the damage his fake news charges would ultimately cause to free press and democracy. Acosta said that on February 16, 2017, after he had jousted with Trump in a press briefing over the firing of National Security Advisor Michael Flynn and the investigation of Russian interference in U.S. elections, he received a call from Trump aide Hope Hicks:

${ }^{25} I d$. at 1055 .

${ }^{26}$ Erik Ugland, Newsgathering, Autonomy, and the Special-Rights Apocrypha: Supreme Court and Media Litigant Conceptions of Press Freedom, 11 U. PENN. J. OF Const. L. 375 (2009).

${ }^{27}$ Jim Acosta, Enemy of the People: A Dangerous Time to Tell the Truth in AmericA (2019). 
"I wanted to let you know that I spoke with the President and he wants you to know that he thought you were very professional today," Hicks said.

"He said, 'Jim gets it,"” she added. Hicks had offered insight into Trump's thinking. When the President called the press "fake news," Hicks was essentially saying this was just an expression, part of the act, something I apparently "get." Other Trump aides and adivsers confirmed this assessment. ${ }^{28}$

Acosta also recounted the multiple death threats he has received from Trump supporters, and he also reported that Trump and his one-time advisor Stephen K. Bannon devised the phrase "enemy of the people" to refer to the press but, disingenuously, the Trump administration still maintains the phrase does not suggest journalists should be attacked. ${ }^{29}$ Further, the phrases "fake news" and "enemy of the people" are now used by populists, demagogues and autocrats around the world to undermine not just journalistic critiques of public officials' conduct but also to attack the very existence of objective truth. ${ }^{30}$ Among those who have reportedly cribbed Trump's pet phrases are Syrian

${ }^{28}$ Jim Acosta, How Trump's “Fake News” Rhetoric Has Gotten out of Control, CNN, June 11, 2019, https://www-m.cnn.com/2019/06/11/politics/enemy-of-the-people-jim-acosta-donaldtrump/index.html?r=https $\% 3 \mathrm{~A} \% 2 \mathrm{~F} \% 2 \mathrm{Fwww}$.google.com $\% 2 \mathrm{~F}$.

${ }^{29} I d$.

${ }^{30}$ See Tom O'Connor, “Fake News!” Following Donald Trump, These Other World Leaders Have Blamed The Media for Troubles At Home, NEWSWEEK, Oct. 11, 2018, available at https://www.newsweek.com/fake-news-donald-trump-world-leaders-1165892. 
President Bashar al-Assad, Philippines President Rodrigo Duterte, Turkish President Recep Tayyip Erdoğan, Venezuelan President Nicolás Maduro, Israeli Prime Minister Benjamin Netanyahu, Hungarian Prime Minister Viktor Orban and Russian President Vladimir Putin. ${ }^{31}$

The relationship between Acosta and Trump officials reached a low point in November 2018 when the White House revoked his press credential after Acosta and Trump sparred during a press briefing. ${ }^{32}$ At one point, Acosta refused to give a White House press briefing room microphone back to an aide who tried to take it from him. CNN filed a lawsuit over the revocation, and a Trump-appointed U.S. District Court judge in Washington, D.C., concluded that CNN and Acosta were likely to succeed on a Fifth Amendment due-process challenge and thus a temporary restraining order against the White House should be granted. ${ }^{33}$ Three days after the judge's order, the White House wrote Acosta a letter saying it was permanently restoring his press pass but also imposing a new set of rules for conduct by journalists. ${ }^{34}$ The new rules allowed only one question per journalist unless Trump or another official granted follow-ups; required

${ }^{31}$ See id.

${ }^{32}$ Brian Flood, Judge orders White House to return press pass to CNN's Jim Acosta, Fox NEWS, November 16, 2018, at https://www.foxnews.com/politics/judge-orders-white-house-returns-press-pass-tocnns-jim-acosta (accessed June 13, 2019).

${ }^{33} I d$.

${ }^{34}$ See Bart Jansen \& William Cummings, White House Backs Down From Fight With CNN, Restores Press Credential for Reporter Jim Acosta, USA TODAY, Nov. 19, 2018, available at https://www.usatoday.com/story/news/politics/2018/11/19/jim-acosta-suspension-possiblypermanent/2053073002/. 
mandatory yielding of the floor, including returning the microphone, after one question; and threatened revocation of a journalist's press pass in case of failure to follow the decorum rules. ${ }^{35}$

Because the White House gave in after the temporary restraining order, the dispute over Acosta's press pass never made it to a litigation stage in which the First Amendment could be applied. Yet, it would seem even the new Trump administration decorum rules for journalists pose constitutional problems. Still, the biggest impact of Trump on journalism could be his larger "war on fact and truth itself." ${ }^{36}$ Journalism in the United States must fight for its credibility, move away from the strong tendency toward false equivalency or balance, and refrain from focusing on every new inflammatory Trump tweet. ${ }^{37}$

The rise of Facebook and other media platforms exploited by domestic and foreign actors happens to have coincided with a decline in local journalism in the United States. In a report titled "Beyond Fixing Facebook," the journalism advocacy organization Free Press recorded that the Bureau of Labor Statistics reported jobs at U.S. newspapers declined from 375,000 in 2014 to 173,000 in $2016 .{ }^{38}$ The report further documents that the University of North Carolina tracked the growing phenomenon of "news deserts," showing the United States lost $20 \%$ of its newspapers since 2004 and that

${ }^{35} I d$.

36 Timothy Zick, The First AMENDMENT In THE TRUMP ERA 21 (2019).

${ }^{37}$ Id. at 22 .

38 Timothy Karr \& Craig Aaron, Beyond Fixing Facebook, FrEE PRESS, February 2019, https://www.freepress.net/sites/default/files/2019-02/Beyond-Fixing-Facebook-Final_0.pdf. 
900 communities are without local news sources. ${ }^{39}$ The study concluded the decline in local news is correlated with drops in civic engagement. It noted the power of socialnetwork algorithms to "gather people into like-minded groups and promote to them the content that will generate the strongest reaction" and stated that these factors, combined with advertising, create "an efficient machine for spreading misinformation and hate." 40 Free Press proposed to tax social-media advertising and fund a public interest media endowment that would support local journalism and media literacy. Yet even those measures might struggle to contain the deleterious effects of social media on U.S. democracy and associated journalistic activities.

Facebook CEO Mark Zuckerberg, in the first half of 2018, testified both in the U.S. Congress and the European Parliament. The half-trillion-dollar company had come under fire for a scandal involving Cambridge Analytica, a political data firm that surreptitiously accessed and sold information about Facebook users' preferences and friends. ${ }^{41}$ One of the individuals behind the company was Bannon, the alt-right leader who served as a key advisor to the Trump campaign in 2016 and later to the Trump administration in the White House. The effect of Cambridge Analytica's exploitation of fifty million accounts is still hard to pin down, but both the June 2016 vote by Britons to leave the European Union and the November 2016 U.S. election of Trump seem to have
${ }^{39} I d$.
${ }^{40} I d$. at 7.
${ }^{41}$ See Kevin Granville, Facebook and Cambridge Analytica: What You Need to Know as Fallout Widens, N.Y. TIMES, Mar. 19, 2018, available at https://www.nytimes.com/2018/03/19/technology/facebook-cambridge-analytica-explained.html. 
been influenced by the company's activities. According to The Guardian, "Cambridge Analytica's own claims suggest that its tens of thousands of propaganda items were viewed billions of times."

Further, Zuckerberg's damage control efforts in 2018 also related to the fact that U.S. criminal prosecutors led by special counsel Robert S. Mueller III in February 2018 indicted thirteen Russian individuals and three Russian organizations for interfering with the U.S. presidential election in $2016 .{ }^{43}$ The indictment alleges that the Russian troll farm known as the Internet Research Agency created false U.S. personas and spread divisive propaganda on social media, including Facebook and Twitter, in an effort to get Trump elected. ${ }^{44}$ The Internet Research Agency also bought political ads on Google, posted videos on YouTube and promoted memes on Instagram that expertly trolled Americans about divisive issues relating to race, religion and politics. ${ }^{45}$

In 2019, Reporters Without Borders ranked the United States 48th in its international Press Freedom Index, a drastic drop of twenty-eight places in just nine

${ }^{42}$ Tim Adams, Facebook's Week of Shame: The Cambridge Analytica Fallout, THE GUARDIAN, Mar. 24, 2018, available at https://www.theguardian.com/technology/2018/mar/24/facebook-week-ofshame-data-breach-observer-revelations-zuckerberg-silence.

${ }^{43}$ See U.S. House of Representatives Permanent Select Committee on Intelligence, Exposing Russia's Effort to Sow Discord Online: The Internet Research Agency and Advertisements, at https://intelligence.house.gov/social-media-content/.

${ }^{44} I d$.

${ }^{45}$ See Nicholas Thompson \& Issie Lapowsky, How Russian Trolls Used Meme Warfare to Divide America, WIRED, Dec. 17, 2018, https://www.wired.com/story/russia-ira-propaganda-senate-report/. 
years, from 20th in 2010. ${ }^{46}$ Reporters Without Borders has compiled the report each year since 2002, and the group analyzes data from 180 countries to compile its rankings.

Countries are ranked on a scale of zero to 100, with zero denoting the best conditions for the press and 100 denoting the worst. ${ }^{47}$ These scores are based on data collected regarding seven indicators. ${ }^{48}$ The countries and territories analyzed are then placed into five categories describing the situation in that country or territory: good, satisfactory, problematic, difficult or very serious. ${ }^{49}$

${ }^{46} 2019$ World Press Freedom Index - A Cycle of Fear, REPORTERS WITHOUT BORDERS, https://rsf.org/en/2019-world-press-freedom-index-cycle-fear (accessed June 7, 2019).

${ }^{47}$ The World Press Freedom Index, REPORTERs WiTHOUT BORDERS, https://rsf.org/en/worldpress-freedom-index (accessed June 7, 2019).

${ }^{48}$ See Reporters Without Borders, Detailed Methodology, RSF.ORG, https://rsf.org/en/detailedmethodology (accessed June 7, 2019) ("Pluralism (Measures the degree to which opinions are represented in the media). . . Media Independence (Measures the degree to which the media are able to function independently of sources of political, governmental, business, and religious power and influence).... Environment and Self-Censorship (Analyses the environment in which news and information providers operate).... Legislative Framework (Measures the impact of the legislative framework governing news and information activities).... Transparency (Measures the transparency of the institutions and procedures that affect the production of news and information).... Infrastructure (Measures the quality of the infrastructure that supports the production of news and information)... [and] Abuses (Measures the level of abuses and violence)").

${ }^{49} I d$. 
In 2019, Reporters Without Borders found the situation in $37 \%$ of the countries analyzed to be problematic and $40 \%$ to be difficult or very serious. ${ }^{50}$ This means that only $24 \%$ of the 180 countries analyzed provide a good climate for the press. ${ }^{51}$ As such, the increasingly precarious position of the press is a global issue, not just one observed in the United States. ${ }^{52}$ In fact, in every report since 2013, Reporters Without Borders has found a decrease in press freedom indicators in every region of the world except Asia, which saw a slight uptick in its regional score from 42 to 41 over that period. ${ }^{53}$ However, the report noted the "biggest deterioration in supposedly better regions," including, prominently, the United States. ${ }^{54}$

The United States' decline over the last nine years is notable and alarming. At a current score of 48 , the United States dropped three points in just one year, falling for the first time into the "problematic" category. ${ }^{55}$ The report points to a variety of reasons for the increasingly hostile climate in the United States that caused this most recent hit to its ranking to occur, and issuing the following, sobering conclusion:

Never before have U.S. journalists been subjected to so many death threats or turned so often to private security firms for protection. Hatred of the media is now

${ }^{50} 2019$ World Press Freedom Index - A Cycle of Fear, REPORTERS WITHOUT BORDERS, https://rsf.org/en/2019-world-press-freedom-index-cycle-fear.

${ }^{51} I d$.

${ }^{52} I d$.

${ }^{53} I d$.

${ }^{54} \mathrm{Id}$.

${ }^{55} I d$. 
such that a man walked into the Capital Gazette newsroom in Annapolis, Maryland, in June 2018 and opened fire, killing four journalists and one other member of the newspaper's staff. ${ }^{56}$

Reporters themselves are also raising concerns about the decline in protection that they experience on the job and observe as professionals. Dan Rather, long-time CBS news anchor with more than sixty years as a professional journalist, ${ }^{57}$ called the state of the free press in America "a crisis greater than I have ever seen in my lifetime and perhaps in any moment in this nation's history." ${ }^{58}$ Individual journalists have reported fearing for their safety while on assignments that once would have presented little danger, particularly while covering political rallies for Trump. CNN's Acosta warned that the angry rhetoric directed toward the press by Trump, both generally and at these events specifically, could "result in somebody getting hurt."59 Slate reporter Mark Stern reports receiving regular death threats, many of which state the sentiment that "Trump wants

\footnotetext{
${ }^{56} I d$.

${ }^{57}$ See Dan Rather Biography, ENCYCLOPEDIA OF WORLD BIOGRAPHY, https://www.notablebiographies.com/news/Ow-Sh/Rather-Dan.html (accessed June 7, 2019).

${ }^{58}$ Dan Rather \& Elliot Kirschner, Why a Free Press Matters, ThE ATLANTIC, Aug. 16, 2018, https://www.theatlantic.com/ideas/archive/2018/08/why-a-free-press-matters/567676/.

${ }^{59}$ Max Greenwood, CNN's Acosta: I'm Worried Trump's Rhetoric Toward Media “Will Result in Somebody Getting Hurt, " THE HILL, July 31, 2018, https://thehill.com/homenews/media/399815-jimacosta-im-worried-trumps-rhetoric-toward-media-will-result-in-somebody.
} 
people like [him] gone. ${ }^{960}$ News organizations have also publicly decried recent erosions to press freedom. CNN issued a statement in late 2018 denouncing Trump's retaliatory revocation of Acosta's press credentials, stating that such actions are "not only dangerous, they are disturbingly un-American." ${ }^{\circ 61}$ Freedom House aimed the following suggestion at the United States:

Press freedom is one of the most fundamental pillars of American democracy, and constitutional protections in the United States are stronger than in any country in the world. Citizens could easily forget this amid media mudslinging and incendiary commentary. Political leaders and teachers should reiterate the extent to which we all benefit from professional journalists who hold those in power to account. $^{62}$

These circumstances point to the need for the United States to pay increased attention to the legal and social protection of journalists in performing their professional functions. Given the need for broad literacy and education about the definition and role of journalism, as well as the traditional reticence of

${ }^{60}$ Mark Joseph Stern, I am a Gay Jew in Trump's America. And I am Afraid for My Life, SLATE, Nov. 9, 2016, https://slate.com/human-interest/2016/11/i-am-a-gay-jew-in-trumps-america-and-i-amterrified.html.

${ }^{61}$ Brian Stelter, White House Pulls CNN Reporter Jim Acosta's Pass After Contentious News Conference, CNN BUSINESS, Nov. 7, 2018], https://www.cnn.com/2018/11/07/media/trump-cnn-pressconference/index.html.

${ }^{62} I d$. 
U.S. jurists and journalists to give substantive meaning to the Press Clause, some consideration of international human rights law is in order. The international law freedom of journalism carries the potential to legally protect journalism in ways that U.S. free-speech jurisprudence does not, including notably as it relates to anti-journalism activities by private entities and individuals.

\section{Scholars Advocate IndePEndent Meaning in Journalism Protections}

The events of recent years — including the Supreme Court's decision in Citizens United $v . F E C^{63}$ and the attacks on the press by politicians led by Trump - have some U.S. scholars calling for an awakening of the First Amendment's Press Clause. ${ }^{64}$ In reality, scholars have been making this argument for decades. ${ }^{65}$ But now, jurists also

${ }^{63} 558$ U.S. 310 (2010).

${ }^{64}$ See RonNell Andersen Jones \& Lisa Grow Sun, Enemy Construction and the Press, 49 ARIZ. ST. L.J., 1301, 1363-66 (2017); West, supra note 24, at 1068-70; Sonja R. West, The Bully and the Press, TAKE CARE, Oct. 5, 2017, https://takecareblog.com/blog/the-bully-and-the-press (accessed October 20, 2018).

${ }^{65}$ See, e.g., David A. Anderson, The Origins of the Press Clause, 30 UCLA L. REV. 455 (1982) (noting the possibility for free press clause jurisprudence in the areas of confidential sources, access to prisons and courtrooms, newsroom searches, and invasive discovery in defamation actions against journalism organizations while concluding that historical sources supported an independent Press Clause); C. Edwin Baker, The Independent Significance of the Press Clause Under Existing Law, 35 HOFSTRA L. REV. 955, 1026 (2006) (calling the failure to distinguish the Press Clause both a "theoretical mistake" and a "pragmatic mistake"); Jon Paul Dilts, The Press Clause and Press Behavior: Revisiting the Implications of Citizenship, 7 COMM. L. \& POL’y 25 (2002) (““TThe Press Clause requires some kind of heightened analysis of the First Amendment implications of press behavior.”); Leonard W. Levy, On the Origins of the 
have chimed in. Now-retired Supreme Court Justice John Paul Stevens, joined by three other Justices, suggested in his partially dissenting opinion in Citizens United that the Press Clause should have meaning independent of the Speech Clause. "[T]he press," Justice Stevens wrote, "might be able to claim special First Amendment status, and therefore . . . some kinds of identity-based distinctions might be permissible after all.",66

The constitutional law scholar and former federal circuit judge Michael W. McConnell agreed that Citizens United should have been decided as a Press Clause and not a Speech Clause case because the anti-Hillary Clinton documentary in question fell within the functional definition of press activity. ${ }^{67}$ If so, McConnell argued, some of the problems following the opinion would be avoided because financial contributions in politics - not part of the functional definition of the press - could be regulated even if expenditures to express a message could not.

The renewed interest in the Press Clause suggests hope for journalism to solidify, or re-establish, its societal role in the face of the stress brought to its economic model by technological and societal changes ${ }^{68}$ and the threat to its legitimacy as an independent

Free Press Clause, 32 UCLA L. REv. 177 (1984) (disagreeing with Anderson's 1982 approach but not with the idea of an independent Press Clause); Melville B. Nimmer, Introduction - Is Freedom of the Press a Redundancy: What Does it Add to Freedom of Speech?, 26 HASTINGS L.J. 639, 658 (1975) (“[F]reedom of the press as a right recognizably distinct from that of freedom of speech is an idea whose time is past due.”).

66558 U.S. at 433 n.57 (Stevens, J., dissenting in part).

${ }^{67}$ Michael W. McConnell, Reconsidering Citizens United as a Press Clause Case, 123 YALE L.J. 412 (2013).

${ }^{68}$ See SAm Lebovic, FREE SPEECH \& UNFREE NEWS (2016). 
truth arbiter by the onslaught of autocratic attacks. Of course, even vigorous Press Clause jurisprudence is not an answer to all the issues facing contemporary journalists, but an awakened Press Clause could empower both institutional press actors and noninstitutional actors conducting press activities. ${ }^{69}$ An initial obstacle remains the longdiscussed thorny question of how to define the press. Here, international law scholarship and jurisprudence provide some guidance, particularly in distinguishing an individual journalism-function-based right from an institutional press or media right.

Noting that only $14 \%$ of the world's population lives in countries rated as "free" by Freedom House, one international-law scholar argued that news media are not merely a means to an end but rather deserve human rights law protection in their own right. ${ }^{70}$ International human rights law recognizes the value of free expression in facilitating other rights, ${ }^{71}$ but the focus on broad free expression rights and the facilitation of other rights may have diluted attention needed for press freedom specifically. To combat the decline of press freedom in developed and developing areas, according to one international law researcher, scholars and advocates must insist on press freedom as a stand-alone right with government oversight as its core function. ${ }^{72}$

${ }^{69}$ See RonNell Andersen Jones, Litigation, Legislation, and Democracy in a Post-Newspaper America, 68 WASH. \& LEE L. REV. 557 (2011).

${ }^{70}$ Wiebke Lamer, Promoting the People's Surrogate: The Case for Press Freedom as a Distinct Human Right, 15 J. HuM. RIGHTS 361, 363 (2016).

${ }^{71}$ See UN Human Rights Committee, General Comment 34, CCPR/C/GC/34 (2011) [hereinafter GC 34] at III 3-4.

${ }^{72}$ See Lamer, supra note 70, at 373-76. 
Scholars suggest one of the key reasons for a journalism right in international law is that journalism serves a distinct role to prevent government abuse of power while expression broadly defined has other goals. The general and broad free expression rights may serve to facilitate individual self-fulfillment or autonomy $;^{73}$ enable the search for truth in the marketplace of ideas $;{ }^{74}$ protect minority voices $;{ }^{75}$ provide a societal safety valve $;{ }^{76}$ and facilitate democratic decision-making. ${ }^{77}$ The press right could serve these functions as well, at times, but they are not the focus of journalistic freedom under international human rights law. In particular, journalism in international law plays virtually no autonomy or self-fulfillment role. Instead, the primary purpose of freedom of the press is to provide for a publicly interested government watchdog — the so-called Fourth Estate whose investigations and publications would keep the branches of government in check. ${ }^{78}$

Amid a flurry of contemporary scholarly discussions of international human rights and freedom of expression, ${ }^{79}$ there are both professional practical guides to foreign and

${ }^{73}$ See David A.J. Richards, Free Speech and Obscenity Law: Toward a Moral Theory of the First Amendment, 123 U. PA. L. REV. 45 (1974).

${ }^{74}$ See Abrams v. United States, 250 U.S. 616, 630 (1919) (Holmes, J., dissenting).

${ }^{75}$ See LeE C. Bollinger, THE TOLERANT SOCIETY 97-100 (1988).

${ }^{76}$ See Thomas EMERSON, THE SyStem OF FrEedOM OF EXPRESSION 7 (1970).

${ }^{77}$ See Alexander Meiklejohn, The First Amendment Is An Absolute, 1961 SuP. CT. REv. 245, 256.

${ }^{78}$ Lamer, supra note 70, at 365-66. See also Vincent Blasi, The Checking Value in First Amendment Theory, 1977 AM. B. FounD. ReS. J. 521.

${ }^{79}$ See Lamer, supra note 70. 
international media $\operatorname{law}^{80}$ as well as scholarly examinations of the protections afforded to journalism specifically. ${ }^{81}$ European scholar Herdis Thorgeirsdottir discussed the need to distinguish individual journalists and journalistic activities from institutional media, in order to preserve the purposes of international-law protections for journalism:

Journalists, who must provide radical critique of society and its institutions, censor themselves out of fear and timidity vis-à-vis corporate interests. Owners and advertisers are in a position to use their economic advantage to manipulate the information flow and opinion formation. Journalists operating within the complex economic, social and political fabric of the market-based media are not in a position to go against powerful interests. That would require personal sacrifices without any rewards or guarantees. Self-censorship within the press is as effective as any legal repression in earlier times in conscripting the press to the establishment. $^{82}$

Thorgeirsdóttir further analyzed jurisprudence from the European Court of Human Rights suggesting that international law freedom of journalism could include

${ }^{80}$ See, e.g., Charles J. Glasser, JR., InTERnAtIONAL LiBEL \& PRIVACY HANDBOOK: A GLOBAL REFERENCE FOR JOURNALISTS, PUBLISHERS, WEBMASTERS, AND LAWYERS (2013).

${ }^{81}$ See, e.g., JAN OSTER, MEDIA FrEEDOM AS A FundAMENTAL Right (2015); JAN OSTER, EUROPEAN AND INTERNATIONAL MEDIA LAW (2017).

${ }^{82}$ Herdís Thorgeirsdóttir, Journalism Worthy of the Name: An Affirmative Reading of Article 10 of the ECHR, 22 NETHERLANDS Q. OF H.R. 601, 612 (2004). 
protection against private actors as well as state actors. ${ }^{83}$ Thorgeirsdóttir calls this "freedom within the media" and admits that it is not yet fully defined and established. ${ }^{84}$ Yet, the need for an individual rather than institutional freedom of journalism is clear. Journalism, she says, "needs in particular to be on guard against the powerful alliance that has been stepped up in recent decades between the elected authorities, which in theory is 'the government of the people, by the people, for the people,' but has teamed with corporate interests." 85

Similarly, the British journalism rights advocate Aidan White wrote that "the growth of the open information landscape has created a new debate about what distinguishes journalism from free expression. ..."86 International law, White pointed out, grants protections to individuals engaged in journalism that are not available to others — non-discriminatory credentialing or accreditation for specific events or locations, guarantees of pluralism, freedom of movement, and ability to shield confidential sources in some instances. ${ }^{87}$ He recognized the growing breach between journalists and their employers, singling out Rupert Murdoch's media holdings as particularly in need of "a rights-based corporate culture" in order to preserve both
${ }^{83} I d$. at 612-613.
${ }^{84} I d$. at 613.
${ }^{85} I d$. at 614 .
${ }^{86}$ Aidan White, A New Vision of Values, Accountability and Mission for Journalism, in TARLACH McGonagle \& Yvonee Donders EDS., The United NATIONS AND FREEDOM OF EXPRESSION AND INFORMATION: CRITICAL PERSPECTIVES 350 (2015).
${ }^{87} I d$. 
journalism and international human rights law standards. ${ }^{88}$ In the United States, White said, Fox News has "abandoned journalistic norms on behalf of its political allies, developing a curious revenue model based upon populist, biased and 'attack dog' journalism. $" 89$

Thorgeirsdóttir and White agree the international law freedom of journalism carries with it responsibilities. This is true generally of freedom of expression under Article 19, which calls them "special duties and responsibilities" regulation as long as the regulation passes muster under a necessity and proportionality test described in detail later in this article. White, who founded the Ethical Journalism Network in 2012 after twenty-five years of building the International Federation of Journalists in 126 countries, puts the responsibility for monitoring performance of journalistic duties and responsibilities squarely on journalists and their associations. ${ }^{91} \mathrm{He}$ notes, however, some efforts at "discreet use of law to underpin and promote journalism as a public good." 92 Oster has made an extensive argument for media freedom as a standalone human right but he does not separate journalists from their owners. ${ }^{93}$ Significantly, Oster points out that international human rights law carries with it an obligation for

\footnotetext{
${ }^{88} I d$. at 354 .

${ }^{89} I d$.

${ }^{90}$ International Covenant on Civil and Political Rights, Article 19, adopted Dec. 19, 1966, entered into force Mar. 23, 1976, 999 U.N.T.S. 171 [hereinafter ICCPR].

${ }^{91} I d$. at $350-56$.

${ }^{92} I d$. at 353.

${ }^{93}$ See OSTER, MEDIA FREEDOM, supra note 81, at 24-55.
} 
nations to protect human rights, such as for journalism, from impairment by private entities and individuals in some cases. ${ }^{94}$

In its commentaries and adjudications on ICCPR Article $19,{ }^{95}$ the Human Rights Committee provides a comprehensive and vibrant view of the role of journalism under international human rights law. An understanding of how the Human Rights Committee already has defined the function of journalism suggests that one of the most frequently discussed obstacles to an individual journalism right with independent legal meaning is not insurmountable.

\section{International Human Rights LAW Protections fOR JournalisM}

Although not binding international law, the 1948 Universal Declaration of Human Rights establishes lofty aspirations for global protection of freedom of expression. In that Declaration, the United Nations General Assembly stated, "Everyone has the right to freedom of opinion and expression; this right includes freedom to hold opinions without interference and to seek, receive and impart information and ideas through any media and regardless of frontiers." 96 The International Covenant on Civil and Political Rights, in Article 19, expanded the UDHR's discussion of media to emphasize they include

${ }^{94} I d$. at $102-09$.

${ }^{95}$ ICCPR has been joined by 173 countries. The United States signed the treaty in 1977 and ratified it in 1992. See United Nations Human Rights Office of the High Commissioner, Status of Ratification Interactive Dashboard, at https://indicators.ohchr.org/ (accessed January 9, 2020).

${ }^{96}$ Universal Declaration of Human Rights, Article 19, adopted Dec. 10, 1948, UNGA Res. 217 A(III). 
communications made "orally, in writing or in print, in the form of art, or through any other media...."97

ICCPR Article 19 clarifies, however, that restrictions may be imposed on free expression in case of countervailing interests. The justification given for these restrictions is that the right to freedom of expression carries "special duties and responsibilities." 98 Several of the interests implicate journalism. First, the free expression right may be restricted if a country's laws specify that the restriction is necessary to protect the rights or reputations of others. Second, the right to free expression may be restricted for reasons of national security and public order, health or morals. The restrictions must be explicitly stated in law and justified as necessary in a democratic society. This test of proportionality established in Article 19 measures the legality of a government restriction on free expression by how well the government regulation fits the need for it.

Although Article 19 does not specifically mention journalism within the larger free expression landscape, ${ }^{99}$ the principal soft-law commentary by the Human Rights Committee establishes the parameters of the proportionality test as applied to journalism in international law. The Committee in its General Comment 34, released in 2011,

${ }^{97}$ ICCPR, supra note 90, at Article 19 II 3.

${ }^{98} \mathrm{Id}$.

${ }^{99}$ Another section of ICCPR singles out the press; Article 14 makes clear that journalists have a presumed right to attend criminal legal proceedings and the only exceptions should be narrow and must be justified. The role of the press within that structure is to provide independent oversight - a watchdog function - to ensure the stated rights are actually given and to inform the public about the proceedings. 
engaged in extensive analysis of the contours of the journalism right in ICCPR Article 19. ${ }^{100}$ General Comment 34 singles out journalism among other forms of free expression because it enables a broad range of opinion and expression rights, ${ }^{101}$ constitutes a cornerstone of democracy, and ensures that governments do not infringe (or allow others to infringe) on other fundamental human rights in ICCPR. ${ }^{102}$ General Comment 34 envisions an independent and uncensored press that is protected in its ability to gather news and information so that it may inform the public on government activities and other issues of public importance. ${ }^{103}$

As the treaty implementation body of ICCPR, the Human Rights Committee is both reactive and proactive. The Committee, which is made up of eighteen international human rights law experts who each serve four-year terms, monitors compliance with ICCPR both by hearing individual adjudications charging violations of the treaty provisions and by publishing commentaries - in the form of General Comments and Concluding Observations - defining standards and providing guidance to nations that are parties to ICCPR. The Human Rights Committee, in General Comment 34, has concluded the right to free expression is so important that it may not be subject to reservations by nations that join ICCPR, meaning that all parties to the treaty accept free

${ }^{100} \mathrm{GC} 34$, supra note 71 at IIII 11, 44.

${ }^{101}$ Other forms of free expression mentioned are political discourse, commentary on public affairs or one's own affairs, canvassing, human rights dialogue, cultural and artistic expression, teaching, religious discourse, commercial advertising, and even some offensive speech although hate speech may be regulated. See id. at II 11.

\footnotetext{
${ }^{102} I d$. at $\mathrm{II} 13$.

${ }^{103} I d$.
} 
expression as a fundamental right that must be protected and respected. Further, General Comment 34 says no derogations, or suspensions of rights in case of emergency, are allowed in the case of free expression. Finally, Article 19 is not subject to countries' subjective interpretations, known as margin of appreciation. ${ }^{104}$

Distinguishing freedom of journalism from other forms of free expression is one of the hallmarks of international law. Although the United States First Amendment has been held not to distinguish free press from free speech, Article 19 of ICCPR and other international law provisions take a different approach. By attempting to define the role of free journalism within the larger freedom of expression landscape, and by applying the proportionality test with full consideration for the unique contribution to society of journalism, international law gives journalism an opportunity to stand apart from other forms of expression. The particular functions and definition of freedom of journalism under international law can be categorized in four ways.

\section{Freedom of Journalism Is Narrower But Stronger Than Freedom of Expression Under the Proportionality Test}

While international law cannot anticipate every situation in which a government entity could attempt to regulate journalism, the Human Rights Committee has given extensive guidelines for applying the proportionality test in case of attempted government restrictions on journalism. The government's interest in secrecy and efficiency (or other goals) cannot justify refusal to disclose to journalists any government-held documents

\footnotetext{
${ }^{104} I d$. at IIII $5,36$.
} 
and information that are in the public interest. ${ }^{105}$ The role of journalism is particularly important, even essential, in the context of political campaigns, and therefore the proportionality test would not allow restriction of journalistic coverage of candidates and issues in that setting. ${ }^{106}$ Further, the Committee asserted, the proportionality test would not allow, under any circumstance, a physical attack, arbitrary arrest, torture, threat to life or murder of a journalist merely for doing journalism. ${ }^{107}$ Although describing the freedom of journalism in broad language, the United Nations Special Rapporteur who investigated the murder of Khashoggi affirmed, "There can hardly be a greater 'interference' with freedom of opinion and expression than killing a journalist or disappearing him in an apparent attempt to silence him."

Although national security is one of the potential justifications for regulating free expression, the proportionality test of Article 19(3) does not permit withholding or suppressing information of legitimate public interest if that information does not actually harm national security. This section of General Comment 34 explicitly forbids prosecution of journalists under treason, official secrets, sedition or other laws merely for publishing government information that does not actually harm national security. ${ }^{109}$ The proportionality test also accounts for the high value placed on journalistic scrutiny of public figures and public officials. General Comment 34 notes that the Human Rights

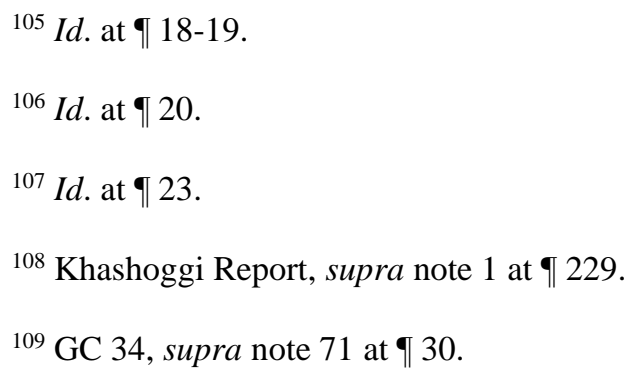


Committee found Angola in violation of ICCPR Article 19 for jailing a journalist named Rafael Marques de Morais for making good-faith accusations, based on his investigative reporting, of corruption by the Angolan president and the president's daughter. ${ }^{110}$ In referencing that case, the Committee in General Comment 34 reiterated that the proportionality test requires that:

$[R]$ estrictive measures must conform to the principle of proportionality; they must be appropriate to achieve their protective function; they must be the least intrusive instrument amongst those which might achieve their protective function; they must be proportionate to the interest to be protected.... The principle of proportionality has to be respected not only in the law that frames the restrictions but also by the administrative and judicial authorities in applying the law.... The principle of proportionality must also take account of the form of expression at issue as well as the means of its dissemination. ${ }^{111}$

The international law proportionality test, then, treats journalism differently and with more protection — than other forms of free expression. ${ }^{112}$ Public order, the

${ }^{110} I d$. at II 34.

${ }^{111} I d$. (internal quotation marks omitted).

${ }^{112}$ For an extensive discussion of this point, see OSTER, MEDIA FREEDOM, supra note 81, at 24-54. Oster discusses at length the contributions of journalism to public discourse and matters of public interest, which are by nature higher on the priority scale and favor freedom of journalism over any attempt at government regulation under the proportionality test. 
Committee wrote, might justify certain restrictions on speech and even the pursuit of contempt of court proceedings, but as suggested already, public order could not be used as a pretense to censor or punish journalistic scrutiny of public officials' conduct while in office. ${ }^{113}$ Racial hate speech may be curtailed but good-faith investigative journalism about public officials, even if unknowingly false, should not be. ${ }^{114}$ The Committee has turned back attempts by government officials in nations that have joined ICCPR to prevent opposition candidates from talking with journalists and to cut off public access to news during election periods. ${ }^{115}$ Legitimate journalistic scrutiny of public officials is protected under Article 19 regardless of whether those government officials feel upset, embarrassed or defamed. ${ }^{116}$ A government ban on a specific newspaper, or governmentimposed onerous licensing conditions on a broadcast news organization, would not be compatible with Article 19. ${ }^{117}$ In fact, the Committee went so far as to say penalizing a journalist solely for criticizing the government "can never be considered to be a necessary restriction." 118

The Committee's General Comment 34 provides further guidance about government regulation of journalism that would not pass the proportionality test. Use of government subsidies and advertisement to control news content is not justifiable. ${ }^{119}$

\footnotetext{
${ }^{113}$ See GC 34, supra note 71 at II 31.

${ }^{114} I d$. at IIII $47,50-52$.

${ }^{115} \mathrm{Id}$. at II 37.

${ }^{116} I d$. at II 38 .

${ }^{117} I d$. at II 39.

${ }^{118} I d$. at II 42 .

${ }^{119} I d$. at II 40.
} 
Favoring one news publication over another in accessing news is not proportional to a legitimate societal need, either. ${ }^{120}$ Government licensing of journalists is incompatible with Article 19, particularly in light of the fact that the function of journalism can be filled at any given time by a variety of people, regardless of whether they are considered institutionally affiliated professional journalists. ${ }^{121}$ Accrediting journalists for access to specific events or locations may be justifiable but not if done in a subjective way to favor or disfavor certain journalists based on their professional status or past published or broadcast content. ${ }^{122}$ Article 19 would rarely approve of a journalist being restricted to travel. ${ }^{123}$ Furthermore, Article 19 of ICCPR encompasses a qualified journalistic privilege in the case of confidential news sources. ${ }^{124}$ News coverage of terrorists and their activities plays an important public function and should not be restricted. ${ }^{125}$ In summary, international law affords near-absolute protection to the function of journalism - a good-faith effort to discover and disseminate truth, especially about matters of public interest such as elections, politics and the performance of public officials. Of course, even countries that have signed and ratified ICCPR do not always comply. In those cases, the Human Rights Committee, the body charged with implementing ICCPR, has found nations to be out of compliance with Article 19 in
${ }^{120} I d$. at II 41.
${ }^{121} I d$. at II 44 .
${ }^{122} I d$.
${ }^{123} I d$. at II 45 .
${ }^{124} I d$.
${ }^{125}$ Id. at II 46. 
individual instances of litigation before the Committee as well as in broader Concluding Observations to a periodic country reporting and review process. In applying the proportionality test, the Committee rarely finds government restriction of journalism to be justified even though a variety of other expressive activities have been allowed to be regulated. The international-law right to free journalism is narrower but closer to absolute than the general right to free expression.

\section{Freedom of Journalism Applies to Individuals Who Act Independently and in Good Faith to Seek and Disseminate Truth in the Public Interest}

The UN Human Rights Committee went to great lengths in 2013 to outline the role of independent journalism to seek and disseminate truth in the public interest. Despite lack of jurisdiction to reach a conclusion, the Committee nonetheless considered journalism rights important enough to write a long opinion in a case alleging violations

committed by Kazakhstan against a journalist named Almas Kusherbaev. ${ }^{126}$ Kazakhstan had not endorsed the individual complaints mechanism in the Optional Protocol to ICCPR at the time the events occurred, and thus the Committee felt it was precluded from reaching a conclusion of violation by Kazakhstan. Still, the Committee seized the opportunity to discuss the role of journalism in discovering and disseminating truth. ${ }^{127}$ The journalist worked at an independent newspaper in Almaty called Raszhargan, which published an article in 2008 about the place of Kazakhstan in the global economy in light

${ }^{126}$ Kusherbaev v. Kazakhstan (Communication No. 2027/2011), UN Doc CCPR/C/107/D/2027/2011 (2013).

${ }^{127} I d$. at IIII 3.5-3.8. 
of the government's decision to ban grain exports. In particular, the article focused on a member of the country's parliament named Romin Madinov. ${ }^{128}$

Although Madinov claimed the article defamed him, and he ultimately succeeded in obtaining a judgment of approximately $\$ 200,000$ (US) against Kusherbaev, the Human Rights Committee expounded at length on the arguments in favor of free journalism. The Committee asserted:

International courts have emphasized that the duty of the press goes beyond mere reporting of facts; its duty is to interpret facts and events in order to inform the public and contribute to the discussion of matters of public importance. There is very little scope for restrictions on political debate. ${ }^{129}$

The Committee further asserted that both the public and private or business interests of a public official are subject to a higher level of public and journalistic scrutiny than would be the case with a private individual. ${ }^{130}$ Given Kazakhstan's status as a major grain producer, the Committee said there was great public interest in the country's efforts to deal with complex economic problems. The role of a member of parliament in that environment was subject not only to the freedom of a journalist to report but became part of the journalist's duty to report. ${ }^{131}$
${ }^{128} I d$.
${ }^{129} I d$. at $\mathbb{I} 3.3$.
${ }^{130} I d$.
${ }^{131} I d$. at $\mathbb{1}$ 3.7. 
In the Kazakhstan case, one of the key issues left unresolved by the Committee dealt with the protection afforded to a journalist who acted independently and in good faith to get the truth but may have been unable, ultimately, to prove the truth of his or her assertions. The Committee repeated, without necessarily endorsing, the arguments by the journalist based on a European Court of Human Rights decision "that it would be unacceptable for a journalist to be debarred from expressing critical value judgments unless he or she could prove their truth." 132

In a case from Uzbekistan, the Committee limited somewhat the protection for erroneous journalism by concluding that a journalist's rights had not been violated by a judgment of defamation based on accusations of corruption for which the complainant university professor had been acquitted in criminal court. ${ }^{133}$ That case, then, stands for the proposition that Article 19 does not protect journalists in the case of demonstrably false statements about private citizens. Yet, in other cases the Human Rights Committee has included false statements, if made in good-faith belief in their truth, within the ambit of free-journalism protections. This is particularly true when the statements concern public officials.

The Committee gave latitude to a journalist using sarcasm when alleging wrongdoing by a leader of the Socialist Party of Serbia. ${ }^{134}$ The Committee found a

${ }^{132} I d$. at $\mathbb{I}$ 3.6.

${ }^{133}$ Allakulov v. Uzbekistan (Communication No. 2430/2014), UN Doc CCPR/C/120/D/2430/2014 (2017).

${ }^{134}$ Bodrožić v. Serbia and Montenegro (Communication No. 1180/2003), UN Doc CCPR/C/85/D/1180/2003 (2006). 
violation of Article 19 where the national courts convicted the journalist, Zeljko Bodrožić, of criminal insult while taking literally his exaggerated and sarcastic commentary. ${ }^{135}$ Even the national courts had acknowledged that to the extent the journalist spoke factually, his statements were true and correct. ${ }^{136}$

Meanwhile, the Committee held Angola violated the Article 19 rights of journalist Rafael Marques de Morais when government officials jailed him for forty days without informing him of any formal criminal charges against him. ${ }^{137}$ The journalist was tried and convicted of defamation and slander for his news articles alleging corruption by the Angolan president, José Eduardo dos Santos. The conviction was improper under international law, according to the UN Human Rights Committee. In their decision, Committee members emphasized that "a free and uncensored press or other media" is of "paramount importance ... in a democratic society."138 The Committee further noted the country's president "is subject to criticism and opposition" and the Angolan courts wrongly did not allow the journalist to assert truth as a defense to the libel charge. ${ }^{139}$

Freedom of Journalism Prioritizes a Government Watchdog Role With Core Values of Justice and Civic Virtue

${ }^{135} \mathrm{Id}$. at II 8 .

${ }^{136} I d$. at II 2.2

${ }^{137}$ Marques de Morais v. Angola (Communication No. 1128/2002), UN Doc CCPR/C/83/D/1128/2002 (2005).

${ }^{138} I d$. at II 6.8.

${ }^{139} I d$. 
International law protections for freedom of journalism have at their core the role of journalism to monitor government use of official power and seek to achieve justice and civic virtue in society. International human rights law views journalism as entitled to righteous indignation in the face of public officials who seek to advance their own selfish agendas, have conflicts of interest and engage in hypocrisy. ${ }^{140}$ Agnes Callamard, the U.N. Special Rapporteur investigating the death of Khashoggi, decried not only the murder of Khashoggi and other journalists by government authorities but also the associated culture of impunity. ${ }^{141}$ Given the tendency of rogue governments who harm journalists to insulate themselves from accountability, Callamard emphasized the need for slain journalists to be memorialized with statues, street names, endowed funds, commemoration days and lecture series in order to focus public attention on preventing future officials from harming journalists even when those journalists are critical of officials' conduct. ${ }^{142}$

Large portions of Callamard's 99-page, 513-paragraph report about the death of Khashoggi are dedicated to the protection of journalism as a check on government abuse of official power. Summarizing, Callamard wrote:

As highlighted throughout this report, before he was executed, Mr. Khashoggi had been subjected to silencing and censorship, with his large number of followers

${ }^{140}$ Kusherbaev v. Kazakhstan (Communication No. 2027/2011), UN Doc CCPR/C/107/D/2027/2011 (2013).

${ }^{141}$ Khashoggi Report, supra note 1 at II 29.

${ }^{142}$ Id. at III 29, 452-454. 
and his articles for the Washington Post perceived [by the Saudi government] as unacceptable threats. There is no more fitting legacy than to ensure that others like him are both protected and supported in their efforts to counter incitement, hatred and threat, both on-line and off-line. ${ }^{143}$

As stated previously, General Comment 34 makes abundantly clear that no government could ever show a necessity under Article 19 to attack, torture or kill a journalist based on that person's journalistic work even if highly critical, whether true or false, of a government official or leader. ${ }^{144}$ Although Saudi Arabia is not party to ICCPR, the actions by agents of Crown Prince Mohammed bin Salman to kill and dismember Khashoggi in Istanbul are obviously not in line with the standard of Article 19. The protection of journalism's watchdog role extends well beyond the extreme acts of torture and murder in the case of Khashoggi. Government action against journalists performing their watchdog role are virtually never appropriate under the proportionality test even if those regulations are non-violent, for example censorship or incarceration. ${ }^{145}$

In addition to their government watchdog function, journalists play an educational and cultural role in society that merits a high level of protection from government interference under the proportionality test. The Committee concluded that Uzbekistan violated the Article 19 rights of journalists and readers of a Tajik-language newspaper

\footnotetext{
${ }^{143}$ Id. at II 455.

144 See supra note 107 and accompanying text.

${ }^{145}$ GC 34, supra note 71 at II 34.
} 
called Oina. ${ }^{146}$ The newspaper was repeatedly shut down by government officials and forced to re-register with the government multiple times, which the Committee found inappropriate in light of the newspaper's societal contributions:

"Oina" published articles containing educational and other materials for Tajiklanguage students and young persons, to assist in their education, to promote a spirit of tolerance and a respect for human values, and to assist in their intellectual and cultural development. In addition to publishing reports on events and matters of cultural interest to this readership (including interviews with prominent Tajik personalities), the newspaper published samples of students' work. It also detailed particular difficulties facing the continued provision of education to Tajik youth in their own language, including shortages of Tajik-language textbooks, low wages for teachers and the forced opening of classes using Uzbek as the language of instruction in some schools where Tajik had previously been the only language of instruction. ${ }^{147}$

The Human Rights Committee also concluded, in a case from Canada, that journalists who fail to live up to the high ideals of their profession, including nondiscrimination against peers on the basis of content or opinion, may not be entitled to

${ }^{146}$ Mavlonov and Sa'di v. Uzbekistan (Communication No. 1334/2004), UN Doc CCPR/C/95/D/1334/2004 (2009).

${ }^{147}$ Id. at II 2.2 . 
deference and protection for their activities. ${ }^{148}$ A group of journalists who formed the Canadian Parliamentary Press Gallery had control over media passes to report on activities of the Canadian Parliament and gain full access to its facilities. The Press Gallery had been allowed by the Speaker of the House of Commons to determine who qualified as a journalist entitled to full membership and thus accreditation. Yet the Press Gallery denied repeated applications for membership by Robert G. Gauthier, publisher of the National Capital News. Gauthier asserted that the Press Gallery engaged in favoritism, coercion and even blackmail. By denying Gauthier membership, the Press Gallery prevented him from receiving the benefits enjoyed by other journalists, including free telephones, services of government staff, access to press conferences, office space, access to press releases and government itineraries, parking, permission to take notes in Parliament, and use of the Library of Parliament. ${ }^{149}$

The Canadian government and the Press Gallery, in turn, argued that Gauthier could still access the proceedings of Parliament like any regular citizen, including on broadcast television and the Internet. Transcripts of proceedings were made available in print form within a day. However, the Committee concluded these methods of public access were not sufficient because Gauthier was treated differently by the government and the Press Gallery than other journalists. ${ }^{150}$ To the extent journalists themselves have control over accreditation of journalists, the Committee said, decisions must be made in a non-discriminatory way. Because the government's abdication to the Press Gallery could

\footnotetext{
${ }^{148}$ Gauthier v. Canada (Communication No. 633/1995), UN Doc CCPR/C/65/D/633/1995 (1999).

${ }^{149} I d$. at $\mathbb{\text { II } 1 3 . 6 .}$

${ }^{150} I d$. at $\mathbb{~ I I ~} 11.4$.
} 
result in arbitrary exclusions, the Committee said, the scheme was not necessary and proportional to the government's interest in controlling access by journalists to Parliament. The Committee admonished Canada and the Press Gallery in the future to make their processes "specific, fair and reasonable, and their application should be transparent."151

In another case from Canada, the Committee declined to grant relief to a man named Ernst Zundel who claimed his Article 19 rights were violated by virtue of being denied Canadian citizenship, detained and threatened with deportation in part because of his extensive public Holocaust denial in various forms of news media. ${ }^{152}$ The Committee ultimately concluded that Zundel had failed to exhaust remedies under the Canadian Charter and thus the claim under ICCPR was inadmissible. ${ }^{153}$ Although the Committee did not reach a conclusion on the merits, Zundel's claims of journalistic protection under Article 19 seem extremely unlikely in light of Article 20's prohibition on religious and racist hate speech. ${ }^{154}$ The proportionality test would not likely condemn Canada for punishing and even deporting Zundel for, among other things, intentional false statements denying the historical reality of the Holocaust.

${ }^{151} I d$. at II 13.6.

${ }^{152}$ Zundel v. Canada (Communication No. 1341/2005), UN Doc CCPR/C/89/D/1341/2005 (2007).

${ }^{153} I d$. at 916.2 .

${ }^{154}$ ICCPR, supra note 90 at Article 20 II 2 (“Any advocacy of national, racial or religious hatred that constitutes incitement to discrimination, hostility or violence shall be prohibited by law.”). 


\section{Freedom of Journalism Includes the Right and Responsibility to Protect Itself and Other Fundamental Human Rights}

The adjudications and commentaries of the Human Rights Committee have emphasized the role of journalism in facilitating the fulfillment of human rights. ${ }^{155}$ In order to complete that objective, journalists must stand up for their own distinct and individual journalism rights. In 2014, the Committee held that Belarus had violated the Article 19 right of a journalist named Marina Koktish by denying her accreditation to report on the House of Representatives within the National Assembly. ${ }^{156}$ Koktish, a reporter for the independent newspaper Narodnaya Volya, asserted the denial stemmed from her newspaper's identity as the only independent, non-state-owned, publication attempting to report on the House of Representatives. Although the government had asserted her security clearance was justifiably denied, officials failed to provide any substantiation and so the Human Right Committee rejected that rationale. ${ }^{157}$

The Committee placed great importance on the fact that Koktish's rejected accreditation would result in her being unable to report on the actions of elected officials, which in turn would prevent the newspaper's readers from understanding how their own interests were being served by their representatives. ${ }^{158}$ The Human Rights Committee concluded that journalists' right to access information about public affairs could not be

155 See, e.g., GC 34, supra note 71 at III 3-4.

${ }^{156}$ Koktish v. Belarus (Communication No. 1985/2010), UN Doc CCPR/C/111/D/1985/2010 (2014).

${ }^{157}$ Id. at II 8.4.

${ }^{158} I d$. 
allowed to be subverted by the political interests or preferences of the political party in power: "The free press and other media can therefore access information about the activities of elected bodies and their members and are able to comment on public issues without censorship or restraint and inform public opinion." 159 In this case, it was apparent the denial of Koktish's accreditation was not proportional to a state interest in national security or any other permissible objective. The Committee mandated that Belarus publish the Committee's opinion widely and report within 180 days on the actions taken to resolve the human rights violation. ${ }^{160}$

In her report on Khashoggi's killing, Callamard noted that Khashoggi had been a zealous advocate for democracy and truth in the face of widespread state propaganda, and he ardently fought online hate speech. ${ }^{161}$ Callamard analyzed the relationships among human rights - in the case of Khashoggi, the violation of his right to conduct journalistic activities was inextricably tied to the violation of his right to be free of privacy violations through surveillance and harassment as well as the violation of his right to life. ${ }^{162}$ The Human Rights Committee noted freedom of expression promotes transparency and accountability that are necessary for realization of all human rights, and free expression is closely tied to rights such as freedom of association and assembly as well as the right to vote. $^{163}$

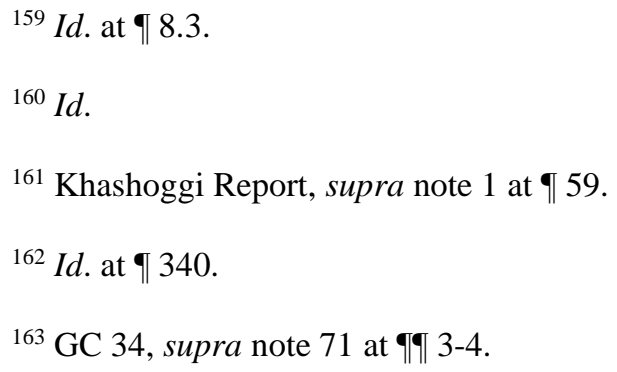


A country's obligation under international human rights law includes the duty to respect, protect and fulfill the realization of human rights. ${ }^{164}$ This means nations must not only refrain from violating human rights themselves but also protect individual human rights from violations by other nations and even private entities or private individuals. Nations must also proactively seek to accomplish full realization of human rights. ${ }^{165}$ Callamard concluded the United States, Turkey and Saudi Arabia are all responsible to investigate Khashoggi's death, prosecute those involved and take measure to ensure such an extrajudicial killing of a journalist will not happen again. ${ }^{166}$ Those countries' duties - especially Saudi Arabia because of the cover-up associated with Khashoggi's killing — could also extend to taking action to prevent human rights abuses by private companies and individuals such as public relations firms, lobbyists and government-contracted journalists. ${ }^{167}$ Callamard also fired a shot across the bow of Facebook and other social media and analytics companies that have allowed their services to be used for propaganda purposes:

Do such companies bear some responsibility for the use made of their services, such as their strategic, technical and communications analyses or well-placed

${ }^{164}$ United Nations Human Rights Office of the High Commissioner, International Human Rights Law, at https://www.ohchr.org/en/professionalinterest/pages/internationallaw.aspx (accessed January 9, 2020).

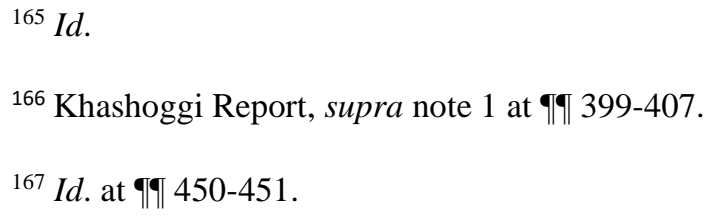


articles and quotes? .... In an era where propaganda and disinformation are denounced as risks to democracy and human rights, including to the right to freedom of expression, such questions ought to be seriously considered. . . . The many companies around the world that are contracted to monitor negative narratives and respond to them, by creating and spreading positive stories, developing national and global communication and political lobbying strategies, ought to determine whether their functions and outputs could be used to violate human rights. ... They also ought to assess whether their products may be used to cover up human rights violations. Finally, the Special Rapporteur believes that companies should consider speaking up in the face of systematic or continuous human rights abuse. ${ }^{168}$

More than a year after the killing of Khashoggi, a lawful U.S. resident, the United States government had made little headway with Saudi Arabia in terms of finding out what happened and why. Although the Trump administration claimed to be pressuring the Saudi government for answers, ${ }^{169}$ there have been no real consequences other than a mostly secret prosecution by Saudi Arabia resulting in five death sentences but not

${ }^{168}$ Id. at II 451.

169 See Stephen Kalin \& Matt Spetalnick, U.S. Pushes for Saudi Progress on Khashoggi Probe Before Anniversary of Killing, REUTERS, June 11, 2019, available at https://www.reuters.com/article/ussaudi-khashoggi-usa/u-s-pushes-for-saudi-progress-on-khashoggi-probe-before-anniversary-of-killingidUSKCN1TC2RY. 
conclusively answering the question of who ordered Khashoggi's death and why. ${ }^{170}$ In fact, Trump's energy secretary, Rick Perry, reportedly approved transfer of nuclear technology secrets to Saudi Arabia two times even after the killing of Khashoggi, but those facts did not come to light until June 2019. ${ }^{171}$ Trump's son-in-law and advisor Jared Kushner reportedly has a close relationship with Mohammed bin Salman and still refuses to acknowledge the CIA's conclusion that the Crown Prince ordered Khashoggi's murder. ${ }^{172}$ Until the facts are all discovered and disseminated, Khashoggi’s killing remains an affront to the Article 19 rights of free journalism everywhere. ${ }^{173}$

\section{CONCLUSION}

The killing of Khashoggi has brought attention to global attacks on journalism as well as the international law protections for freedom of journalism. That individual

${ }^{170}$ See Ben Hubbard, Saudi Death Sentences in Khashoggi Killing Fail to Dispel Questions, N.Y.

TIMES, Dec. 23, 2019, available at https://www.nytimes.com/2019/12/23/world/middleeast/jamalkhashoggi-murder-sentence.html.

${ }^{171}$ Dan De Luce \& Robert Windrem, Trump Admin Gave Green Light to Nuclear Permits for Saudi Arabia After Khashoggi Killing, NBC NEWs, June 4, 2019, https://www.nbcnews.com/news/world/trump-admin-gave-green-light-nuclear-permits-saudi-arabia-aftern1013826.

172 Jonathan Swan, Jared Kushner on MBS, refugees, racism and Trump's legacy, AXIOS, at https://www.axios.com/kushner-mbs-refugees-racism-trump-legacy-a92d1982-4b6f-4164-a0e057d0a746c68e.html (accessed June 13, 2019).

${ }^{173}$ See Randall Lane, The 10 Most Urgent Cases Right Now Impinging a Global Free Press, FORBES, (May 1, 2019), at https://www.forbes.com/sites/randalllane/2019/05/01/the-10-most-urgent-casesright-now-impinging-a-global-free-press/\#3c3dda45623c (accessed June 13, 2019). 
freedom increasingly should be seen as distinct from an institutional media or press right, in part because media organizations may not be sufficiently independent from economic and political perspectives. The freedom of journalism should be further developed in international law and commentary. At this point, the freedom involves certain specific journalistic rights including source confidentiality, non-discriminatory credentialing or accreditation and unrestricted movement within and across national borders. Freedom of journalism is relatively narrow and applied to individuals who complete journalistic functions regardless of whether they hold institutional media jobs. Journalism is a high priority for protection under the test of proportionality that measures whether government regulation is permissible when it impairs fundamental human rights.

Freedom of journalism does not have a state-action requirement in order for legal impairment or infringement to occur. The right may require national governments to accept responsibility for controlling the conduct of private entities and individuals in some cases. The core of freedom of journalism is independent activity to seek and disseminate truth on matters of public interest, and it primarily serves a government watchdog role with justice and civic virtue as central values. The freedom to conduct journalism supersedes virtually all government interests in regulation in part because of journalism's role in promoting the transparency and accountability necessary for the realization of all human rights.

Like other nations that have signed and ratified ICCPR, the United States has bound itself to the international law understanding of journalistic freedom as discussed in this article. However, the United States has not adopted the Optional Protocol that would allow individual complaints against the United States to be heard by the UN Human 
Rights Committee. Effectively, then, the United States has insulated itself from a primary method of enforcement of the treaty. Still, if the United States government is to be taken at its word, the principles and international law standards of Article 19 as interpreted by General Comment 34 should be respected, protected and fulfilled. Doing so could promote public understanding and support, combat the Trump administration's assaults and force private corporations to confront their accountability for propaganda, partisanship and other practices harmful to freedom of journalism. 